\title{
Participation and Elements of Direct Democracy in the Czech Republic: Part II $^{1}$
}

\author{
Petr Jüptner, Pavla Valušová, Ilona Kruntorádová \\ Charles University in Prague, Faculty of Social Sciences \\ Smetanovo nábřeži 6, CZ-110 00 Prague, Czech Republic
}

DOI:10.13165/VPA-15-14-2-09

\begin{abstract}
The present paper further elaborates on the text addressing the issue of direct democracy and direct elections in the Czech Republic, published in the previous issue of the journal. Besides the theoretical and methodological outputs, the first part contained the summary of data for local referenda and their original typology, collected from the authors' own research. The submitted second part analyzes the factors affecting the validity and outcomes of local referenda, which primarily include a voter's turnout. Furthermore, the second part, in particular, targets the analysis of a political discussion on the direct election of executive positions which structurally correlates with the issue of direct democracy. The conclusion is valid for both parts of the text and aims at the total assessment of the conception of direct democracy within the system of multi-level governance in the Czech Republic and its comparison with the prevailing approaches in other European countries.
\end{abstract}

Keywords: Direct democracy, referendum, direct election

Raktažodžiai: tiesiogine demokratija, referendumas, tiesioginiai rinkimai.

\section{Introduction}

In the previous part of this article [19], we presented mainly empirical typology of local referendums, the referenda of which are divided according to their theme into four categories: (1) the territorial changes of a municipality, (2) environment,

1 The article was compiled within the project of the Grant Agency of the Czech Republic No. P408/10/0811 "Instruments for Amalgamation of Fragmented Local Governments. Analysis of Experience and Practice across European Countries". 
(3) matters of internal administration of a municipality and (4) others. In this second part, which is based conceptually and methodologically on the previous article, we analysed factors affecting turnout in the above categories of local referendums on the basis of empirical data. The turnout is a key variable which affects the validity and binding of the results. The discussion about referenda is related to the debate on direct elections which will be followed in this second part of the article. While we worked with the empirical sample obtained in own research in the case of referendum, in case of direct elections, we elaborated on the basis of the analysis of political parties' attitudes, academic discussion, laws, legislative proposals and governmental documents. The conclusion contains the main findings of the content related also to the first part of the article.

\section{Factors affecting the result of local referenda}

The validity of a referendum is based on the turnout of voters in the voting which is particularly influenced by the topic of a local referendum, the size of a municipality and legislation. Even though all the topics in individual referendum categories concern the future development of a municipality, its form and economic capacities to act, the highest average turnout is reached by the voting on territorial changes and the smallest turnout of the voting on the matters involving an internal administration of a municipality (Graph 1).

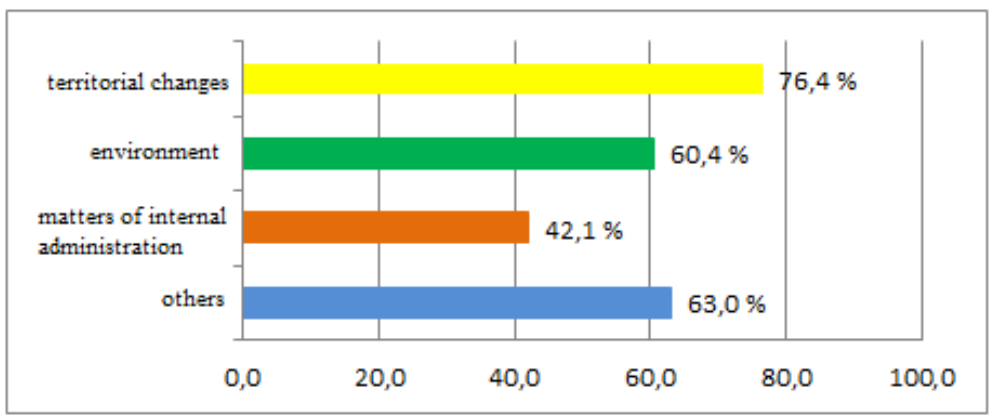

\section{Graph 1. Average turnout in individual referendum categories}

Source: compiled by the authors

Yet, the results of individual referenda define which topics tend to mobilize the citizens (Graph 1). Such questions include the voting on the establishment of new municipalities, or the referenda on the integration or amalgamation of municipalities, the referenda on environmental questions, such as nuclear waste dumps, landfills, mining and livestock breeding, and the category of "others" include the referenda on a radar base. All such voting reached an average turnout higher than $60 \%$. 


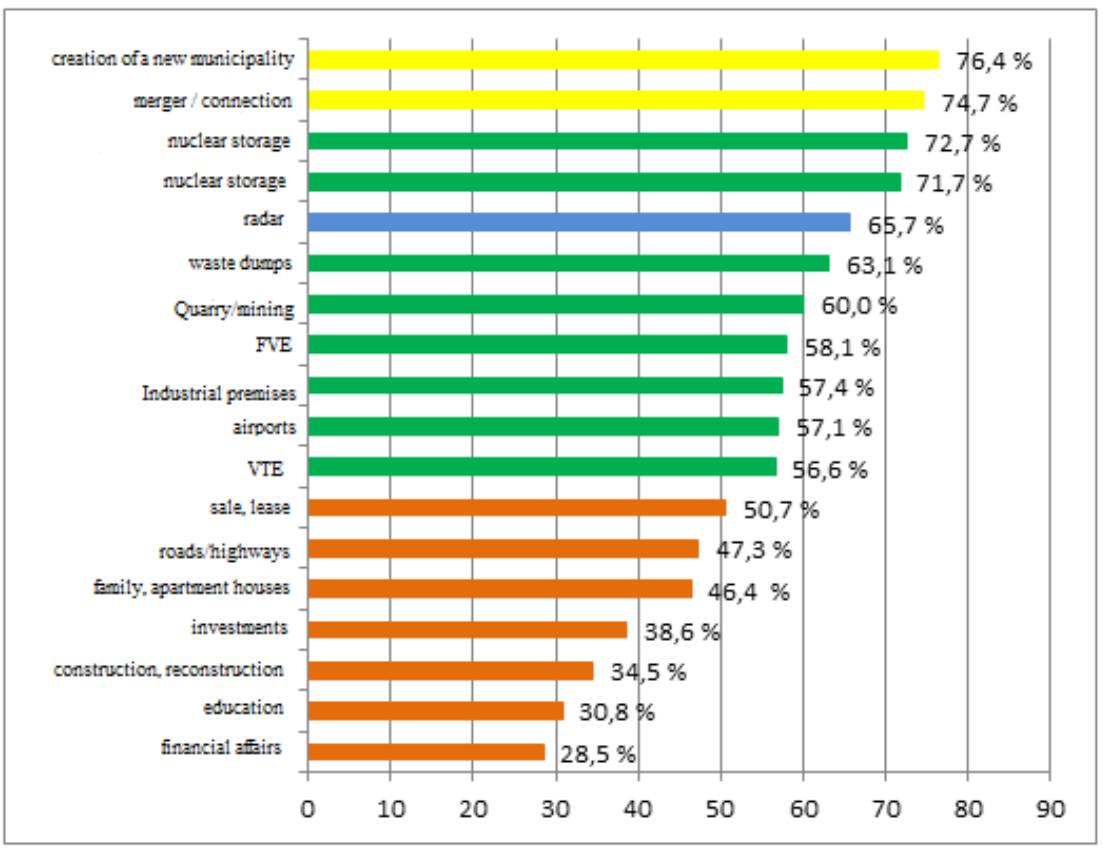

\section{Graph 2. Average turnout in local referenda. The referenda held on the same topic at least three times have been incorporated into the graph}

Source: compiled by the authors

The connection between the size of a municipality and the turnout of citizens in the voting was established on the example of a variety of European countries. The highest average turnout is reached by the referenda held in smaller municipalities. This conclusion may be applied to the Czech Republic, as well. All 154 local referenda out of the total number of 319 votings were held in the municipalities of up to 500 inhabitants. Due to a highly fragmented municipal structure ${ }^{2}$, such a phenomenon is understandable; nonetheless, the turnout of the citizens was also the highest one in these smallest municipalities.

2 More than a half of all the municipalities in the Czech Republic fall under the category of up to 500 inhabitants. 


\begin{tabular}{cccc}
\hline $\begin{array}{c}\text { Number of } \\
\text { inhabitants [1] }\end{array}$ & $\begin{array}{c}\text { Number of held } \\
\text { referenda }\end{array}$ & $\begin{array}{c}\text { Number of invalid } \\
\text { local referenda }\end{array}$ & $\begin{array}{c}\text { Average turnout } \\
\text { (\%) }\end{array}$ \\
\hline do 500 & 154 & 4 & 75,2 \\
\hline $501-2000$ & 119 & 15 & 61,2 \\
\hline $2001-5000$ & 28 & 12 & 44,9 \\
\hline $5001-10000$ & 10 & 8 & 31,8 \\
\hline $10001-50000$ & 7 & 6 & 25,4 \\
\hline nad 50 001 & 1 & 1 & 24,9 \\
\hline Total & 319 & 46 & 64,5 \\
\hline [1] Number of inhabitants at the time a local referendum was held & \\
\hline
\end{tabular}

Table 1. Success rate and average turnout in local referenda reflecting the size of a municipality

Source: compiled by the authors

Important findings are embodied in the fact that the municipalities with above 5000 inhabitants have a significantly lower chance of holding a successful local referendum, as the average turnout reaches around $30 \%$. Such municipalities held in a given time period only 17 votings, of which only three were valid. None of the referenda in the municipalities with above 5000 inhabitants in the sample reached the validity in compliance with the strictest conditions (50\% turnout) and did not even come close to such conditions. Not even a current legislation which requires a significantly lower quorum had an impact on eventually more frequent and successfully held referenda in such big cities. So far, the largest city in the sample, where a local referendum was held, has been Brno. In 2004, it held a referendum on the relocation of a train station and it engaged $24.9 \%$ of the voters. On the contrary, the smallest represented municipality is Ustup, which had only 42 inhabitants at the time the referendum was held in 2010. The referendum was on the construction of a photovoltaic power station with a $93.9 \%$ turnout. If we, for the sake of an evidence value of our conclusions, reflected on the referenda held after the year $2011^{3}$, our findings would be universally confirmed. There have been more attempts to initiate the referenda in larger cities, as well; however, such referenda supported our previous conclusions and were invalid due to a low turnout (the case of Prague city quarters, Liberec, Pardubice, Semily and Jablonec nad Nisou). Sporadically though, successful initiations have emerged since 2013, for example, the referendum against the sale of water and sewer network and the ban on slot machines ${ }^{4}$ in Dvurr Králové nad Labem (approximately 16000 inhabitants) or a relocation of a swimming stadium in

3 The current list has been acquired from Mgr. Štěpán from the Ministry of Interior.

4 The fact that the referendum was simultaneously declared on two questions might have contributed to the mobilization of voters. 
Písek (almost 30000 inhabitants). So far, the largest success has been the referendum against the construction of a department store in the centre of the fourth largest Czech city Plzeň, which mobilized $41.5 \%$ of the voters in January 2013 ; they voted against this investment plan $^{5}$ in absolute majority.

The legislation itself does not possess a potential to affect the voter's turnout. As an outcome of activities and decisions made by the law-makers, it sets mechanical rules governing local referenda, primarily their quantitative aspect. A relatively low delimitation of quorum required for the validity of a referendum in accordance with the first legislation resulted in a $100 \%$ success rate of such referenda. The referenda held in compliance with this legislation demonstrated the highest average turnout, as well. On the contrary, a success rate significantly dropped upon the adoption of a new and strict condition of 50\% voter's turnout; an average turnout dropped, as well. $30 \%$ of local referenda held while the law was in effect were unable to comply with the limit of $50 \%$. The current compromise legislation shows $20 \%$ failure rate. An average turnout did not increase with a repeated lowering of the quorum; on the contrary, in comparison with the previous law, it remained two percent lower. The values of a turnout prove that distinctly stipulated limits for the validity and legal binding of referenda do not affect the turnout itself. By far, the lowest level of validity has been reached by the referenda held on internal administration of a municipality. On the contrary, the higher levels of validity in the referenda on environmental issues prove a high appeal of such voting.

\section{Direct election of executive positions}

Direct elections are or may be implemented on three levels of the Czech political system - in the municipalities, regions or on a national level. They concern or might concern mayors as the representatives of municipalities, governors as the representatives of regions ${ }^{6}$, and the president of the Czech Republic. Direct elections do not constitute a tradition on the Czech territory. The head of a state as well as the heads of local autonomies do not possess significant executive powers; on local and regional levels, they are only members of collective executives ${ }^{7}$, on a national level the executive lies in the government, derived from the legitimity of a parliament ${ }^{8}$.

5 The data come from an unpublished database of the Ministry of Interior of the Czech Republic.

6 The Czech Republic consists of 14 regions. However, one of them is the capital city of Prague which elects its regional government in compliance with the rules of the elections to the local government.

7 An executive body in regions and municipalities is embodied in the council. The mayors in the smallest municipalities with no instituted council may gain a stronger position in regards to their executive power.

8 Considering the traditions dating back to the period of the so-called First Republic in interwar era, even this arrangement may be considered traditional $[14,1,9]$. 


\section{Institutionalization of direct elections in the Czech political system}

A direct election has not been so far implemented on a local level. In the period of the coalition government of Petr Nečas (2010-2013), there were attempts to implement it in small municipalities. A draft of the constitutional amendment was prepared to make the implementation of a direct election of mayors possible as of the elections of 2014 already. However, due to ambiguous support within the governmental coalition itself and an uncertain possibility to gain the support of a constitutional majority for the proposal in both chambers of the parliament, an eventual implementation of the plan was left for future governments, which did not seize this opportunity or did not assign it a priority in their policy documents. Both versions of governmental analyses on a direct election as well as the proposal of a factual intent of a constitutional amendment did not accept that the position of mayors in the system of local autonomy would remain identical; their position was supposed to be significantly strengthened. One of the proposals implied that a mayor would be directly elected in the municipalities of such a number of councillors which would exclude the institution of a council and the mayor would assume its competences. The function of a mayor and councillor was supposed to become incompatible; however, it was assumed that a mayor could still chair the meetings of a municipal council. The mayor could then appoint his deputy from the ranks of councillors without their approval. The mayors of small municipalities were expected to be elected in a one-round majority system necessitating a relative majority of cast votes. An important question was related to the definition of a "small municipality", in which a direct election was to be implemented in accordance with the policy statement of the government. One option was to set the limit by the number of inhabitants (e.g., 1500); according to the already outlined other option, the way how to elect a mayor would reflect the number of councillors stipulated by a local autonomy. In case of the implementation of the latter proposal, the municipalities with up to 10000 inhabitants could through stipulating a lower number of councillors opt for an alternative model without the institution of a council, but with a directly elected mayor [7].

On a regional level, there were no proposals for legislation on the implementation of a direct election of governors.

Since the year 2001, there have been several drafts of the constitutional amendment which would facilitate the implementation of a direct election of the president. In particular, small center parties and the groups of deputies authored such drafts; the deputies from the ranks of social democrats endorsed several drafts, as well. The coalition government of Petr Nečas (2010-2013) set the implementation of a direct election of the president as its goal and submitted its draft of a constitutional amendment in 2011. The draft was adopted upon the hearings in both chambers of the parliament in 2012 and paved the way for a direct election of the president in 2013. None of the relevant legislative proposals for the implementation of a direct election of the president represented a deviation from a parliamentary system. The 
presidential powers were to remain the same or to be even limited, in such questions as amnesty or appointment of the members of the Bank board of the Czech national bank [18]. Although some of the previous legislative proposals contained a oneround majority system, a two-round system requiring an absolute majority of cast votes dominated the discussions and was implemented in the end ${ }^{9}$. A presidential candidate is required to gain the nomination by 40 deputies $^{10}$ or 17 senators ${ }^{11}$ for his candidacy, or the petition with the endorsement of 50000 signatures of voters in case of a civil candidate.

Political discussions and preferences on direct elections: inspiration, parallels and connections?

A direct election on the local level has been since the very beginning primarily supported by the small parties in the right center of a Czech political spectrum and by the groups of mayors. While the support by the groups of mayors was in particular determined by their individualized conception of politics, in case of small liberal parties, this support was connected with their programmes and a lower participation in local politics. Large established political parties do not actively pursue a direct election; however, none of them considers it wise to oppose to it. The support of concrete proposals reeled off the composition of governmental coalitions. In the period of 2006-2009, the discussions launched on an eventual implementation of a direct election of mayors and corresponding conditions, thanks to the participation of Strana Zelených (the Green party) in the governmental coalition, who prioritized such discussions. In the period of 2010-2013, thanks to the participation of STAN mayor's movement in the governmental coalition [17], a priority was attached to an implementation of a direct election in small municipalities and its preparation. This solution was at the same time acceptable for the leading governmental party ODS, which would not be significantly affected by the implementation of a direct election as it would concern small municipalities only. The plan was never materialized and a new center government did not set its implementation as a priority.

An absence of a relevant discussion on an eventual implementation of a direct election of governors may be blamed on the fact that the regions represent the most recent and not yet fully established level of a Czech political system. Allusions to a possible implementation of a direct election of governors have occurred in the governmental analysis of possibilities of an implementation of a direct election of mayors from the year 2007. Within a basic conception of local autonomy, the analysis implied the necessity to address an eventual implementation of a direct election of mayors with the implementation of a direct election of governors [5]. It constituted the only relevant references to the joint discussion on the implementation of a direct election on both local as well as regional levels. Simultaneously, such a

9 The president is elected in the same way as members of the Senate, the upper chamber of the Czech parliament.

$1020 \%$ of the total number.

$1121 \%$ of the total number. 
reference might have been a certain "nightmare", which was to eliminate the plans of an eventual implementation of a direct election on a local level.

A discussion on a direct election of the president was not associated with the implementation of direct elections on other levels. What motivated the implementation of a direct election of the president was the absence of a favourite candidate of an indirect election upon the end of presidencies of Václav Havel and Václav Klaus and an indirectly related risk of not electing a president or electing a president by a very low number of law-makers in an eventual third round of an election. Complicated progressions of indirect elections also added to the implementation of a direct election as the majority required to elect a president was formed very intricately in them and accusations of corruption and blackmailing of deputies emerged, as well ${ }^{12}$. An important role was played by public opinion, too; it urged the governmental as well as opposition parties to submit the proposals for the implementation of a direct election. In parliamentary discussions preceding the adoption of an implementation of a direct election, almost all relevant parties embraced this election and emphasized their credit for its implementation [18].

Despite the lack of causalities and direct correlations between the discussions on individual levels, we may detect the elements common to all the discussions on such levels. The proposals for an implementation of direct elections are often initiated by the central political entities or the parties which position within a political system will not deteriorate upon the implementation of a direct election. None of the political parties stands against direct elections; however, only a small number actively endorses a direct election [12]. Individual parties approach a direct election pragmatically and their opinions do not originate in a clear conception of a local public administration, but rather in the current state of a political discussion and the position within a party system ${ }^{13}$. An implementation of direct elections is frequently not thoroughly prepared, the proposal for an implementation of a direct election of mayors relied on the analyses containing inaccurate data and assumptions [6]; a direct election of the president was passed by the law-makers despite disapproving viewpoints of their committees [18].

\section{Prospects of direct elections within a Czech political system}

Miloš Zeman was elected in the first direct elections of the president of the Czech Republic; he used the legitimity of a direct election to shift an interpretation

12 For example, the senator Josef Novotný presented the accusations of vote buying.

13 An example of such pragmatism may be an attempt to demarcate small municipalities in order to implement a direct election. An angry Prime Minister Petr Nečas asked the chairman of the parliamentary party TOP09/STAN Peter Gazdík how many inhabitants the municipality Suchá Loz has (Mr Gazdík used to be the mayor of this municipality). $\mathrm{Mr}$ Gazdík replied that there were around 1100 inhabitants and the Prime Minister was said to resolutely conclude that therefore, the mayors will be elected directly in municipalities with up to 1200 inhabitants [6]. 
of the constitution governing his position. He became the target of criticism for appointing the government of officials in 2013 without a prior consultation with the leading political parties $[4,10]$; he was criticized for appropriating the position typical of a semi-presidential or even presidential system. In the upcoming years, we may not exclude the amendments which would specify the presidential powers in the constitution in more detail. Upon the experience gained in the direct election of the president, the opinions advocating a direct election of mayors have diminished; besides, such an election has not been incorporated into the programme points of a new central government.

\section{Conclusion}

1. Heterogeneity in the approaches to direct democracy on a local level almost inhibits finding generally valid characteristics common to a larger group of states linked historically and geographically. Non-binding of the results of voting to municipal bodies may be found in Finland or Italy [8]. A low frequency of voting may be encountered in France or Denmark [2]. Thus, the West European countries often implement non-binding referenda which are often held sporadically only. Some German states and, of course, Switzerland as a "classic" example of direct democracy present an exception to such a tendency in Western Europe [3, 15]. Generally, it may be concluded that the countries in Eastern Europe, or the Visegrad states, hold the referenda more frequently. Such countries feature a higher number of votings as well as the legal binding of referenda for municipal representatives or a possibility to declare a referendum based on the initiative by the citizens. Such a way of the initiation of local referenda is also essential as, unlike the Western European countries, the local autonomy in such countries does not ordinarily initiate the referenda. The above stated features apply to the local referendum in the Czech Republic, as well. A common trait of the mentioned characteristics is a prevailing existence of small municipalities, which is favorable to such a mobilization of voters which secures a declaration and validity of referenda. The Baltic States represent a specific exception in Eastern European countries as their legislation is not familiar with a local referendum at all. In case of Lithuania, we may even speak about adverse conditions for a local referendum due to a very high average size of municipalities.

2. In connection with the discussion on direct elections, the Czech Republic has so far been classified into typical parliamentarian systems [11]; however, due to the shift in constitutional traditions upon the first direct election of the president, the position of the president has fluctuated, minimally for a temporary period ${ }^{14}$. The position of the president in the system will then be closely linked with the personality of Miloš Zeman ${ }^{15}$. Among other things, negative experience with his approach to

14 There is no unanimity among the experts whether a direct election of the president has to necessarily collide with a parliamentary system [13].

15 Also, the personalities of the previous (indirectly elected) presidents Václav Havel and Václav Klaus partially shaped the position of a president in the political system [10]. 
the constitutional definition of the president considerably lowers the chances of an implementation of a direct election of mayors and, together with the Baltic States, the Czech Republic will be one of the few countries in this region which elect the mayors indirectly. In his typology of local systems, Pawel Swianiewicz ranks the Czech Republic among the cluster of countries for which an indirect election of mayors is a characteristic feature [16]. Also, the Czech Republic has recently joined a small group of countries in Central and Eastern Europe, among others comprising Lithuania and Hungary, where the mayors and presidents are elected using different ways. Particularly in the discussions on an eventual implementation of a direct election of mayors, the political actors and government officials reflected on the experience and qualities of a model implemented in Slovakia [7].

3. Although the issue of the elements of direct democracy and direct elections tend to be mixed into political discussions in each state, the mutual coherence is lost during specific implementations. This corresponds not only to the theoretical definition of direct democracy tools, among which direct elections are not usually included [19], but also the experience of the Czech Republic. There is no evident connection between the discussions on the elements of a direct democracy and direct elections in the Czech Republic; it may often not even be found between the implementation of referenda or direct elections on individual levels of the Czech political system. A direct election has only been implemented on a national level which, however, as the only one does not allow a general referendum. The absence of a universal model may be observed in the definition of individual elements and the discussions on them. While the president elected directly does not hold any significant executive powers, an option with a strong mayor has been legislatively prepared for a local level. Similar arrangements may perhaps only be found in the case of the referenda held on local and regional levels.

4. The absence of a clearer conception of an implementation of the elements of direct democracy may in some cases be partly related to the low expertise of the proposals or the pragmatism of political parties. As regards the expertise or underestimation of the issue of direct democracy, it is impossible not to mention an inaccurate and obsolete register of local referenda, which complicates the reflection on the practice of local referenda, crucial for eventual drafts of amendments. Another argument affecting the resulting legislative reality are the flaws in the governmental analytical documents which, for example, led to an incorrect preference of a Slovakian model of direct elections of mayors, although the tradition of the system of public administration and the ways of an implementation of direct elections require the consideration of an Austrian model, as well [7]. The reason for an inspiration by a Slovakian model was apparently only an absence of a language barrier between the two countries or personal contacts between the resort ministries of both countries. The pragmatism of political parties is another important factor, which inhibits the framing of a clear policy towards the referenda and direct elections. Political parties are in regards to their role in a certain "conflict of interests" as the implementation of the elements of direct democracy restrains their power. On the other hand, the 
issues of direct democracy and direct elections are very often tackled by small and opposition parties for their popularity and this places the cartel of established parties under pressure. They have no interest in imposing changes, but they do not want to risk their popularity through their opposition to a direct democracy. Therefore, the decisions on the most significant elements, such as a general referendum or direct elections, will in the future probably be the result of election outcomes in combination with strong impulses into a political system. A prioritized target of all the discussions will be national and local levels as a relatively recently established regional level responds to most trends with a delay.

\section{References}

1. Balík, S. Komunální politika: Obce, aktéři a cíle mistni politiky. Grada Publishing, 2009.

2. Bartáková, P. Referenda ve vybraných zeních. Srovnávací studie č. 1.178. Praha: Parlamentní institut, Parlament České republiky, Kancelář Poslanecké sněmovny, 2006.

3. Gabriel, O., Walter-Rogg, M. Citizen Initiatives and Citizen Referendums - The Consequences for Local Government Decision-Making Processes. German Journal of Urban Studies. 2006, 45(2).

4. Hloušek, V. Heads of State in Parliamentary Democracies: The Temptation to Accrue Personal Power. In Presidents above parties? Presidents in Central and Eastern Europe, Their Formal Competencies and Informal Power. Brno: Muni Press, 2013.

5. Jüptner, P. Ministerská diskuse k př́ipadnému zavedení př́imé volby starostů: vel $\neg m i$ nízká priorita? Acta Politologica. 2009, 1(3).

6. Jüptner, P., Valušová, P., Kruntorádová, I. Elementy of Direct Democracy: Part 1. Public Policy and Administration. 2014, 4(13).

7. Př́imá volba starostů v evropské komparaci a české diskusi. Acta Politologica. 2012, 4(3).

8. Direct Election of Mayors in the Czech Political Debate and within the European Context. In Selected Issues of Administrative Reality. Novo město: Fakulteta za organizacijske študije, 2013.

9. Karjalainen, M. Referendum at Local Level - Dead Letter or Effective Direct Democracy? The Finnish Case. Finland: Department of Political Science/University of Turku, 2010.

10. Klimek, A. Boj O Hrad, Svazek 1. Praha: Panevropa, 1996.

11. Kopeček, L., Mlejnek, J. Different Confessions, Same Sins? Václav Havel and Václav Klaus as Czech Presidents. In Presidents above parties? Presidents in Central and Eastern Europe, Their Formal Competencies and Informal Power. Brno: Muni Press, 2013.

12. Prezident republiky v ústavním systému ČR. In Postavení hlavy státu v parlamentních a poloprezidentských režimech - Česká republika v komparativni perspektivě. Praha: Dokořán, 2008.

13. Mlejnek, J. Postavení hlavy státu v postkomunistických zemích: od pádu komunismu v roce 1989 do roku 2010. Praha: Univerzita Karlova, Fakulta sociálnich věd, 2011.

14. Novák, M. Politologie. Praha: CEVRO: Liberálně konzervativní akademie.

15. Schelle, K. Organizace veřejné správyv letech 1848-1948. Brno: Masarykova univerzita, 1993. 
16. Socher, S., Rehmet, F., Reidinger, F. 15-Jahres-Bericht bayerischer Bürgerbegehren und Bürgerentscheide. 2010. <http://www.mehr-demokratie.de/fileadmin/md/pdf/buergerentscheid/bayern/Bayern_15-Jahresbericht.pdf $>$.

17. Swianiewicz, P. An Empirical Typology of Local Government Systems in Eastern Europe. Local Government Studies. 2013, 39(4): 1-20.

18. Šaradín, P. Direct Elections of Mayors in Czech Republic? Data from Research and Political Support. Contemporary European Studies. 2010, (2).

19. Vlasáková, Š. Př́má volba prezidenta ČR v kontextu české odborné i veřejné diskuze. Diplomová práce (Mgr.). Praha: Univerzita Karlova, Fakulta sociálních věd, Institut politologických studií. Katedra politologie. Vedoucí diplomové práce PhDr. Josef Mlejnek, Ph.D., 2013.

20. ČSÚ. <www.czso.cz>

Petr Jüptner, Pavla Valušová, Ilona Kruntorádová

\title{
Dalyvavimas ir tiesioginės demokratijos elementai Čekijos Respublikoje: II dalis
}

\author{
Anotacija
}

Šiame straipsnyje toliau aptariami ankstesniame žurnalo numeryje pradèti analizuoti tiesioginès demokratijos ir tiesioginių rinkimų Čekijos Respublikoje klausimai. Pirmoje dalyje, be teorinių ir metodologinių įžvalgų, buvo pateikta ir straipsnio autorių surinktų duomenų, susijusių su vietos referendumais ir jų tipologija, santrauka. Antrojoje dalyje analizuojami veiksniai, tiesiogiai veikiantys rinkejjų aktyvumą ir kartu darantys ịtaką vietos referendumų svarumui bei rezultatams. Be to, antroje dalyje analizuojamos politinès tiesioginių vykdomosios valdžios rinkimų diskusijos, kurios struktūriniu požiūriu yra susijusios su tiesioginès demokratijos klausimais. Išvados apima abi teksto dalis ir siekia bendrai ịvertinti tiesioginès demokratijos koncepciją daugiapakopeje Čekijos Respublikos valdymo sistemoje bei palyginti su kitose Europos šalyse vyraujančiais požiūriais.

Petr Jüptner - Prahos Karolio universiteto Socialinių mokslų fakulteto Politikos studijų instituto direktorius, politikos mokslų daktaras.

E. paštas juptner@fsv.cuni.cz

Pavla Valušová - politikos mokslų magistrè.

E. paštas pavla.valusova@seznam.cz

Ilona Kruntorádová - Prahos Karolio universiteto Socialinių mokslų fakulteto Politikos studijų instituto Doktorantūros studijų centro vadovė, politikos mokslų doktorantė.

E. paštas: kruntoradova@fsv.cuni.cz

Petr Jüptner, Doctor of Political Science, Charles University in Prague, Faculty of Social Sciences, Institute of Political Studies, Director.

E-mail: juptner@fsv.cuni.cz

Pavla Valušová, Master of Political Science.

E-mail: pavla.valusova@seznam.cz

Ilona Kruntorádová, Ph.D. student of Political Science, Charles University in Prague, Faculty of Social Sciences, Institute of Political Studies, Head of Centre for Doctoral Studies.

E-mail: kruntoradova@fsv.cuni.cz

Straipsnis redakcijai įteiktas 2014 m rugsèjo mėn.; recenzuotas; parengtas spausdinti 2015 m. birželio mèn. 